\title{
オプティカルインジェクションを用いた単色エネルギー電子ビームの安定生成
}

\author{
小瀧 秀行 \\ 日本原子力研究開発機構 量子ビーム応用研究部門 レーザー電子加速研究グループ (
}

\section{Stable Generation of A Mono-Energetic Electron Beam by Using Optical Injection}

\author{
Hideyuki KOTAKI \\ Japan Atomic Energy Agency, Quantum Beam Science Directorate, Laser-Electron Acceleration Group, \\ 8-1-7 Umemidai, Kizugawa, Kyoto 619-0215
}

(Received July 8, 2012)

\begin{abstract}
Laser wakefield acceleration, based on the effect of plasma waves excitation in the wake of an intense laser pulse, is now regarded as a basis for the next generation of charged particle accelerators. In order to generate a bunch with high quality and stability, required for applications, the electrons should be duly injected into the wakefield and this injection should be controllable. This paper reviews optical injection of electrons into the wakefield for a stable and a controllable electron beam generation. The wakefield is generated by a laser pulse. The second laser pulse collides with the first pulse at 180 and at 135 degrees realizing optical injection of an electron bunch. The electron bunch has high stability and high reproducibility compared with single pulse electron generation.
\end{abstract}

Key Words: Laser acceleration, Optical injection, Laser-plasma interaction, Intense laser pulse, High stability electron beam

1. はじめに

高強度レーザーとプラズマとの相互作用によりプラズ マ波が生成される。生成したプラズマ波による電場 (ウェーク場)によって電子を加速する「レーザー電子加 速」帛は, 現在の汎用加速器である高周波加速器に比べ て, 超短パルスで低エミッタンス(指向性が高い)の電子 ビームを短い加速距離でつくることが可能となるため, 高時間分解能の測定用光源や次世代の加速器のための電 子ビーム入射器として期待され, 各国で研究が進められ ている、レーザー電子加速研究により, エネルギー幅の 狭い準単色エネルギー電子ビーム生成 ${ }^{2-6}$, 数 $\mathrm{cm} の$ 加速 での $1 \mathrm{GeV}$ 電子ビーム生成 ${ }^{7-9)}$ 等の成果が得られている. しかしながら，レーザー加速電子ビームの安定性に問題 があるため，未だ実用化できていない.

電子ビームを, 高周波加速器のように安定に加速する には，電子ビームを加速するための電場であるウェーク 場を安定に生成する必要がある。ウェーク場生成用の レーザーの強度やプラズマ密度が高すぎると, ウェーク 場が壊れてしまい，安定な加速ができなくなる，そこ で, 当初は, ウェーク場が壊れないようにレーザー強度 及びプラズマ密度を調整しウェーク場を生成し, そこに 加速用の電子ビームを外から入射してレーザー加速実験 を行った ${ }^{10)}$. しかしながら, 本研究には, 加速電子ビー
ム生成用の電子ビーム入射器と電子加速のためのレー ザープラズマが必要となる。電子入射器とレーザーの両 方がある施設はほとんどないため, なかなか研究が進ま ず，電子入射及び電子加速ともにレーザープラズマを使 用するようになった。レーザープラズマからの電子入射 には, レーザーにより生成されるプラズマ波の破砕によ る入射が用いられた。

ここで，安定な電子加速に問題が起こった。電子の入 射にはプラズマ波の破砕による自己入射が必要となる が，プラズマ波の破砕はウェーク場を乱し，電子加速が 不安定となる。その結果, ショット毎に電子ビームの発 生方向やエネルギー, 電荷量などがふらついた。安定な プラズマ波をつくり，且つ，プラズマ波の破砕を起こす という矛盾する状況をつくらなければならないため, 1 レーザーパルスで生成したレーザー加速電子ビームを安 定化させるのは, 非常に難しい.レーザー加速生成電子 ビームの安定化のため，プラズマ電子密度分布を利用す る方法 ${ }^{11,12)}$ や，プレパルスコントロールや磁場を用いる 方法 ${ }^{13-15)}$, 価数の高いガスを用いる方法 ${ }^{16,17)}$ などが研究 されている. 安定化の方法の1つとして, 複数レーザー パルスを用いる方法がある ${ }^{18-22)}$ 。この方法は, セット アップが複雑になる。しかしながら，以下のような優位 点がある．複数のレーザーパルスを用いることにより， プラズマ波の励起を担うレーザーパルス(ドライバパル 
ス) と電子入射を担うレーザーパルス(インジェクション パルス)を分離できる。この分離により, 安定なプラズ マ波励起と電子入射を分けることが可能となる。これに より生成電子ビームの安定化及び電子ビームのコント ロールを可能とした。 これを「オプティカルインジェク ション(光による入射)」という ${ }^{18-22)}$.

プラズマ中の電子は，ほぼ光速で動くプラズマウェー ク場に乗っていくことができない. ドライバパルスで生 成したウェーク場に，2つのインジェクションパルスで 電子を入射する方法がEsareyらによって提案され た ${ }^{18-20)}$. インジェクションパルス1と2をプラズマ中で衝 突させ，そのときにできるビート波によりプラズマ中の 電子をドライバパルスで生成したプラズマ波へ入射す る. 3 パルスを用いる場合, 電子入射位置をコントロー ルできるという利点があるが，セットアップが複雑にな るため実験では成功していない，2レーザーパルスを用 いる場合，ドライバパルスで安定なプラズマ波を作り， インジェクションパルスとドライバパルスとの衝突によ り電子の入射を行う ${ }^{21,22)}$ 。 この場合, ドライバパルスが プラズマ波励起と電子入射の両方を担うことになる。し かし, 電子入射とプラズマ波励起の分離はできているた め, 電子ビームの安定化, エネルギーコントロールは可 能である. 2パルスでのオプティカルインジェクション は，フランス及び日本において実験でも証明されている ${ }^{23-25)}$. この2パルスでのオプティカルインジェクション について紹介する。

\section{2. オプティカルインジェクションによる レーザー電子加速の概念}

まず，2レーザーパルスでのオプティカルインジェク

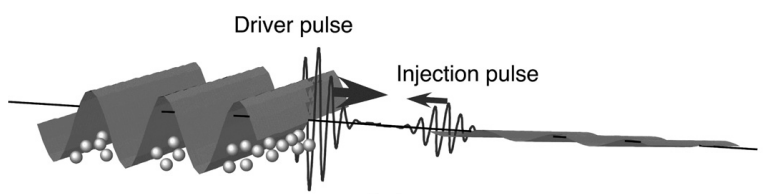

(a)

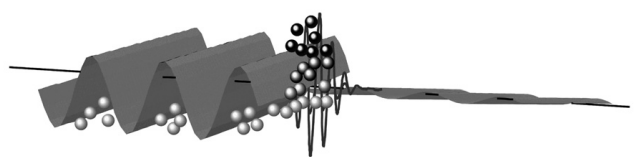

(b)

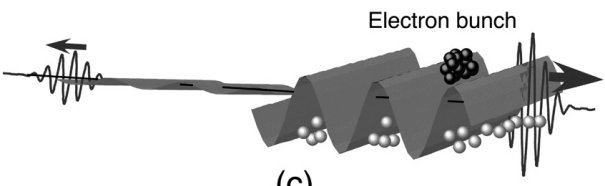

(c)

Fig. 1 A schematic of the optical injection by using two pulses. The driver pulse propagates to the right, and the injection pulse propagates to the left. (a) The driver pulse is a pump pulse to generate a plasma wake. (b) The colliding pulses produce a standing wave to inject plasma electrons into the plasma wake. (c) The injected electron bunch is accelerated by the wake wave.
ションについて説明する. Fig. 1に，2レーザーパルス衝 突入射レーザー電子加速の概念図を示す。ドライバパル ス及びインジェクションパルスは，それぞれ安定で自己 入射のおこらないプラズマ波を励起する(Fig. 1 (a)).

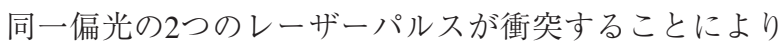
定在波が生成され，その定在波によりプラズマ中の電子 をプラズマ波へ入射する(Fig. 1（b)）。入射された電子 は, プラズマ波により高エネルギーに加速される (Fig. 1 (c))。 ドライバパルスの強度及びプラズマ電子 密度を自己入射が起らない領域まで下げることにより， 安定なプラズマ波を生成でき，その結果として，電子 ビームの安定化ができる，2つのレーザーパルスの衝突 位置のコントロールにより生成電子ビームのエネルギー のコントロールが，衝突する2つのレーザーパルスの偏 光や強度のコントロールにより生成電子ビームの電荷量 のコントロールが可能となる。このようにして, 安定で コントロール可能な電子ビームを, レーザー電子加速に より，生成できるようになる。

Fig. 2に，2次元粒子シミュレーションで得られたプラ

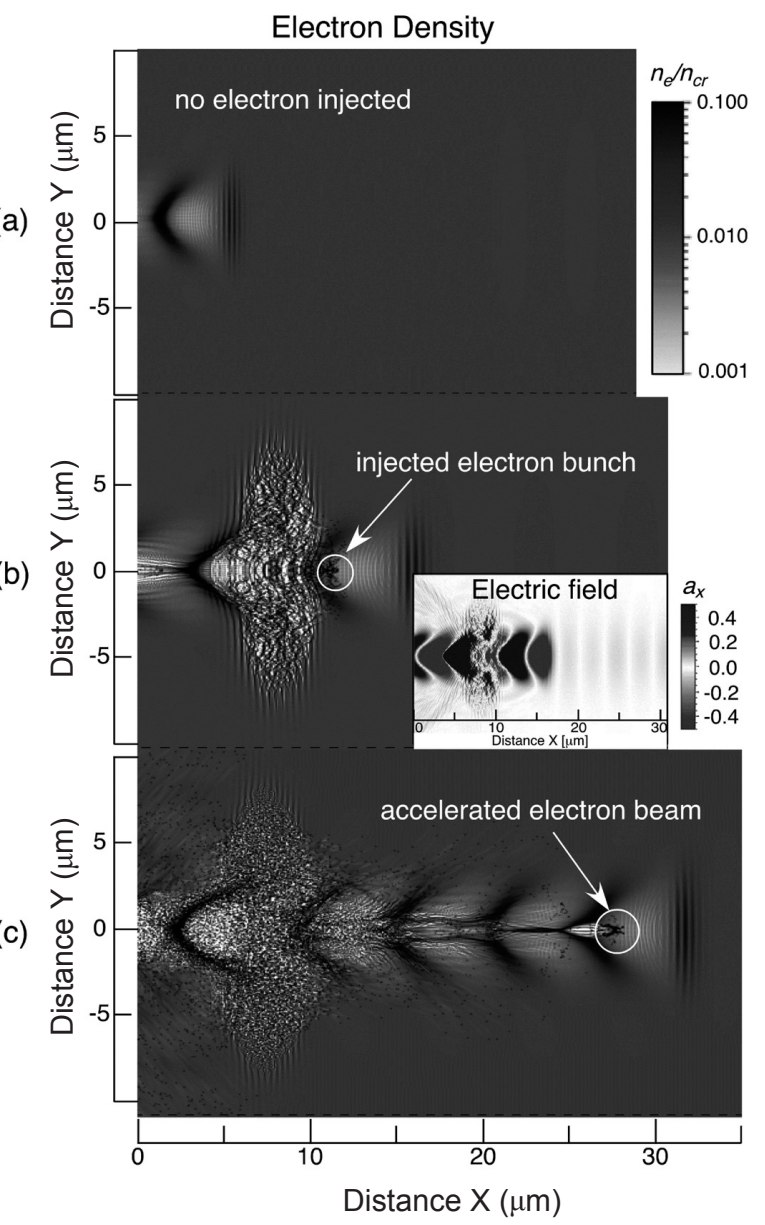

Fig. 2 2D (2 dimensional) PIC (Particle-in-Cell) simulation result of electron density distributions in plasma for $a_{0}=1.25$ and $a_{1}=0.5$. Here $n_{e}$ is electron density, $n_{c r}$ is critical density, and $a_{x}$ is normalized electric field component. (a) No electron is injected in the wakefield. (b) The colliding pulses inject plasma electrons into the wakefield. (c) The injected electrons are accelerated by the wakefield. 
ズマ中の電子密度分布と電子入射時のウェーク場の結果 を示す。このときのドライバパルスの規格化強度, $a_{0}=8.5 \times 10^{-10} \lambda_{0}[\mu \mathrm{m}] I_{0}{ }^{1 / 2}\left[\mathrm{~W} / \mathrm{cm}^{2}\right]$, は 1.25, インジェク ションパルスの規格化強度 $a_{1}$ は0.5である。ここで, $\lambda_{0}$ は レーザーの波長, $I_{0}$ はレーザーの集光強度である。

Fig. 2 (a) は, 2つのレーザーパルスの衝突前で, 電子入 射はまだない.Fig. 2 (b) は, 衝突の瞬間であり。ここ で電子バンチがウェーク場に入射される，入射された電 子バンチは, Fig. 2 (c)のように, ウェーク場で加速さ れる。電子入射は，2つのレーザーパルスが衝突したと きのみ起こる，そのため, 入射された電子バンチは数 フェムト秒という短パルスとなり, 周期が数十フェムト 秒のウェーク場での加速でも，エネルギーが広がらず， 単色エネルギーの電子ビームが生成できる。

また，ウェーク場による加速勾配は $100 \mathrm{MeV} / \mathrm{mm}$ 程度 あり, 数 $\mathrm{mm}$ の加速で数 $100 \mathrm{MeV}$ 電子ビームを得るこ とができる。電子ビームのエネルギーを上げるため，今 後, 加速距離の長尺化 ${ }^{26,27)}$ や多段加速を行っていく必要 がある。

\section{3. 完全対向衝突による安定電子ビーム生成}

実験は, 超短パルス・高強度のチタンサファイアレー ザーを用いて行われ，日本及びフランスで成功し

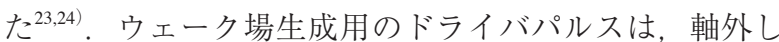
放物面鏡 (off-axis parabolic mirror: OAP) でガスジェット へ集光し，インジェクションパルスは，ドライバパルス

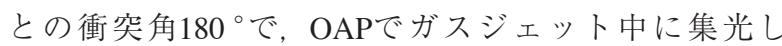
た。電子ビーム測定は, 永久磁石・蛍光板・CCDカメ ラで構成された，電子スペクトロメータを用いて，電子 ビームのエネルギー, エネルギー分散, 角度広がり, 電 荷量を測定した。

まず，安定なプラズマ波を励起するため，自己入射 (1 パルス)でのレーザー電子加速実験を行い，自己入射が 起こらないプラズマ電子密度を調べた。プラズマ電子密

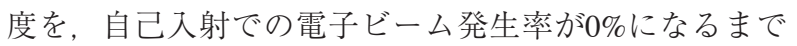
下げ，その状態で，オプティカルインジェクションによ るレーザー電子加速実験を行った．Fig. 3に日本での実

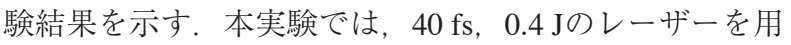
いて実験を行った。このときの集光強度は $I_{0}=3.0 \times$

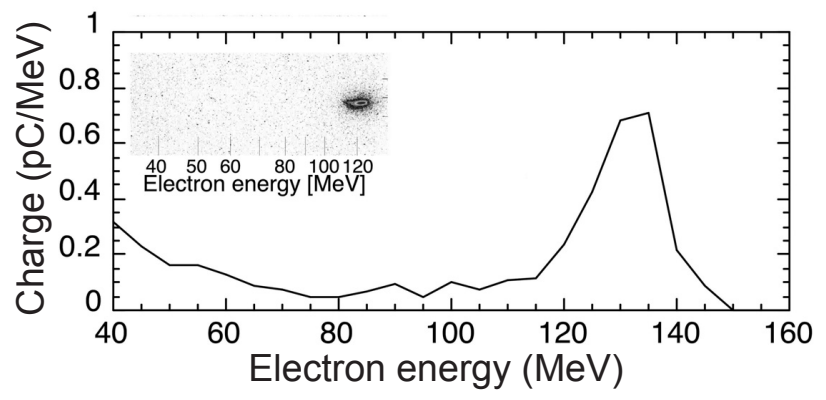

Fig. 3 A typical image of an energy distribution of the electron bunch. The monoenergetic electron bunch has a peak energy of $134 \mathrm{MeV}$ and an energy spread of $3.5 \%$ (rms).
$10^{18} \mathrm{~W} / \mathrm{cm}^{2}$ で，規格化強度 $a_{0}$ は $1.2, \quad$ プラズマ密度は $1.0 \times 10^{19} \mathrm{~cm}^{-3}$ である. 図のように, インジェクション パルスを入射することにより安定な単色エネルギーの電 子ビームが生成される。生成電子ビームのピークエネル ギーは $134 \mathrm{MeV}$ ，エネルギー分散は $3.5 \%(\mathrm{rms})$, 電荷量

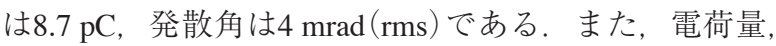
エネルギー等の安定性も向上した，本実験により，オプ ティカルインジェクションでの高品質電子ビーム生成に 成功した.

また，フランスでの実験では，2つのレーザーパルス のタイミング調整により衝突点を変化させ，電子ビーム の加速距離をコントロールすることにより, 生成電子 ビームのエネルギーをコントロールし，50２00 MeVの 電子ビームエネルギーのコントロールに成功した ${ }^{23)}$. エ ネルギー分散は，10〜20 MeV(FWHM)である。

\section{4. 斜め衝突による電子ビーム生成}

完全対向衝突によるオプティカルインジェクションの 場合, 衝突点のコントロールや安定化がしやすいが, 戻 り光によるレーザーシステムへのダメージが懸念され る。ささらに, 高エネルギー電子ビームの進行方向に，イ ンジェクションパルス用の光学系があり，電子ビーム利 用の妨げとなる。そこで， $70 \mathrm{fs} ， 0.2 \mathrm{~J}$ のレーザーを用い て， 135 衝突でのオプティカルインジェクションによ るレーザー加速実験を行った ${ }^{24)}$.

完全対向衝突での実験時と同様，安定なプラズマ波を 励起するため，まず自己入射(1パルス)でのレーザー電 子加速実験を行い, 自己入射が起こらないプラズマ電子 密度を調べた。 Fig. 4に，インジェクションパルスあり

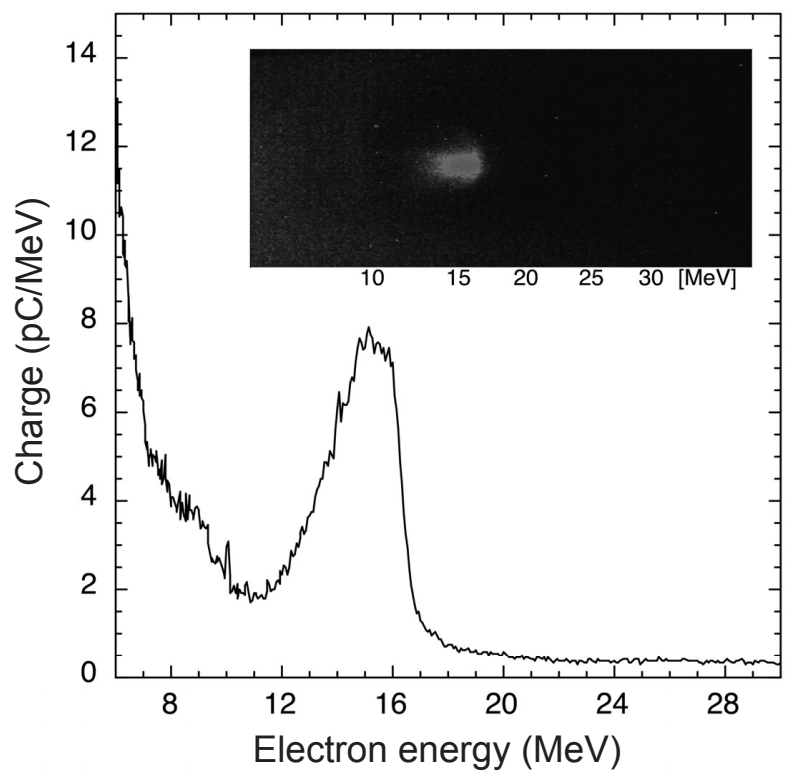

Fig. 4 A typical image of an energy distribution of the electron bunch obtained by the countercrossing injection at $n_{e}=3.95 \times 10^{19} \mathrm{~cm}^{-3}$, and a projection of the image onto the energy axis. The quasimonoenergetic electron bunch has peak energy of $15 \mathrm{MeV}$ and energy spread of $7.8 \%$ (rms). 
の場合の電子ビームのエネルギースペクトルを示す。こ のときの自己入射による電子ビームの発生率は $0 \%$ あ゙ る。図のように，インジェクションパルスの入射により 単色エネルギーの電子ビームが生成される. 生成電子 ビームのピークエネルギーは $15 \mathrm{MeV}$, エネルギー分散 は7.8\% (1.2 MeV) (rms), 電荷量は30 pCである。このエ ネルギーではエネルギー分散は現在使用されている高周 波加速器より大きいものの, さらに加速すればエネル ギー分散は小さくなる。計算及びシミュレーションより 予想されているパルス幅は $10 \mathrm{fs}$ 以下であり, 瞬間の電流 量は, 高周波加速器よりも高い值を示している。 また工 ミッタンスも, 同等かより良い值を示している。斜め衝 突での実験では，完全対向衝突の場合に比べて，レー ザー出力が小さかったため，電子ビームエネルギーは， 完全対向衝突実験時ほどのびなかった。しかし，電子 ビームのエネルギーは, 2レーザーパルス衝突後の, ド ライバパルスにより生成されるウェーク場での加速で決 まってくるため, 同一のレーザーを用いれば, 同じエネ ルギーが得られる。

次に生成電子ビームのパラメータのふらつきを比較し た(Fig. 5). 自己入射の起こるパラメータでオプティカ ルインジェクションを行った場合，プラズマ波の破砕に よる乱れたウェーク場に，オプティカルインジェクショ ンによる電子入射が起こるため, 両者を比較しての安定 化の議論はできない。 また，ウェーク場の乱れがないパ ラメータでは，自己入射が起こらないため，自己入射に よる電子ビームが生成できず，両者の比較はできない. そこで, オプテイカルインジェクションでのプラズマ密 度は, 自己入射の起こらない $3.95 \times 10^{19} \mathrm{~cm}^{-3}$, 自己入射 でのプラズマ密度は, 自己入射による加速電子が最も安 定であった $4.40 \times 10^{19} \mathrm{~cm}^{-3}$ とした。これらを比較した結 果，エネルギー・エネルギー分散・電荷量ともオプティ カルインジェクションの方が安定であった。この結果よ り, 斜め入射でのオプティカルインジェクションでも, 生成電子ビームの安定化を示した.

完全対向入射及び斜め入射によるオプティカルイン ジェクションについて示した. どちらの方法にも, メ リット・デメリットがある。ささらに, 衝突角度によって も, 衝突点のコントロールのしやすさや, セットアップ のつくりやすさ等に違いが生ずる. 今後, それらについ

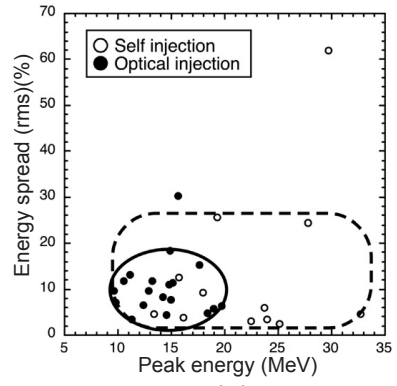

(a) (b)

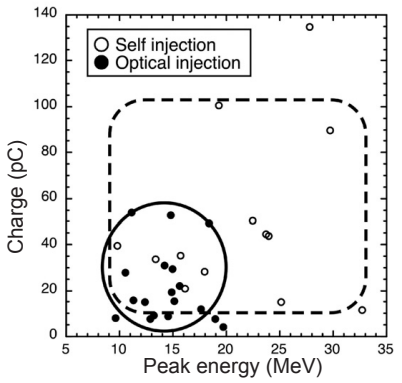

Fig. 5 The stability of the self-injection and the optical injection. The stability of the optical injection is higher than that of the self-injection.
ても，実験及び検討が必要であると考えられる，

$$
\text { 5. まとめ }
$$

レーザー電子加速は, 小型・超短パルス・高品質の電 子ビーム源として期待されている。しかしながら，ビー ム特性の安定化及びコントロールが難しく，未だ，その 利用研究に至っていない。本報告では, その安定化とコ ントロールするための方法として筆者が提案した「2パル スでのオプティカルインジェクションによるレーザー電 子加速」の解説及び本手法による実験結果について紹介 した。レーザー電子加速研究の進展により，ビーム特性 の安定性の向上やコントロールが可能となってきている が，電荷量コントロールや単色性等，未だ既存の加速器 の性能に及んでいない. 今後, 超短パルス・高品質の レーザー加速電子ビームを用いた応用研究が, 現実のも のとなり, 超高速現象の測定や加速器の小型化等へつな がることを期待する.

\section{参考文献}

1) T. Tajima and J. M. Dawson: Phys. Rev. Lett. 43 (1979) 267.

2) E. Miura, K. Koyama, S. Kato, N. Saito, M. Adachi, T. Nakamura, and M. Tanimoto: Appl. Phys. Lett. 86 (2005) 251501.

3 ) S. P. D. Mangles, C. D. Murphy, Z. Najmudin, A. G. R. Thomas, J. L. Collier, A. E. Dangor, E. J. Divall, P. S. Foster, J. G. Gallacher, C. J. Hooker, et al.: Nature 431 (2004) 535.

4) C. G. R. Geddes, Cs. Toth, J. van Tilborg, E. Esarey, C. B Schroeder, D. Bruhwiler, C. Nieter, J. Cary, and W. P. Leemans: Nature 431 (2004) 538.

5) J. Faure, Y. Glinec, A. Pukhov, S. Kiselev, S. Gordienko, E. Lefebvre, J.-P. Rousseau, F. Burgy, and V. Malka: Nature 431 (2004) 541.

6) A. Yamazaki, H. Kotaki, I. Daito, M. Kando, S. V. Bulanov, T. Zh. Esirkepov, S. Kondo, S. Kanazawa, T. Homma, K. Nakajima, et al.: Phys. Plasmas 12 (2005) 093101.

7) W. P. Leemans, B. Nagler, A. J. Gonsalves, Cs. Toth, K. Nakamura, C. G. R. Geddes, E. Esarey, C. B. Schroeder, and S. M. Hooker: Nature Phys. 2 (2006) 696.

8) K. Nakamura, B. Nagler, A. J. Gonsalves, Cs. Toth, K. Nakamura, C. G. R. Geddes, E. Esarey, C. B. Schroeder, and S. M. Hooker: Phys. Plasmas 14 (2007) 056708.

9) N. A. M. Hafz, T. M. Jeong, I. Choi, S. K. Lee, K. H. Pae, V. V. Kulagin, J. H. Sung, T. J. Yu, K.-H. Hong, T. Hosokai, et al.: Nature Photon. 2 (2008) 571

10) M. Kando, H. Ahn, H. Dewa, H. Kotaki, T. Ueda, M. Uesaka, T. Watanabe, H. Nakanishi, A. Ogata, and K. Nakajima: Jpn. J. Appl. Phys. 38 (1999) L967.

11) S. Bulanov, N. Naumova, F. Pegoraro, and J. Sakai: Phys. Rev. E 58 (1998) R5257.

12) C. G. R. Geddes, K. Nakamura, G. R. Plateau, Cs. Toth, E. CormierMichel, E. Esarey, C. B. Schroeder, J. R. Cary, and W. P. Leemans: Phys. Rev. Lett. 100 (2008) 215004.

13) T. Hosokai, K. Kinoshita, A. Zhidkov, K. Nakamura, T. Watanabe, T. Ueda, H. Kotaki, M. Kando, K. Nakajima, and M. Uesaka: Phys. Rev. E 67 (2003) 036407.

14) T. Hosokai, K. Kinoshita, A. Zhidkov, K. Nakamura, H. Kotaki, M. Kando, K. Nakajima, and M. Uesaka: Phys. Plasmas 11 (2004) L57.

15) T. Hosokai, K. Kinoshita, T. Ohkubo, A. Maekawa, M. Uesaka, A. Zhidkov, A. Yamazaki, H. Kotaki, M. Kando, K. Nakajima, et al.: Phys. Rev. E 73 (2006) 036407.

16) M. Mori, K. Kondo, Y. Mizuta, M. Kando, H. Kotaki, M. Nishiuchi, M. Kado, A. S. Pirozhkov, K. Ogura, H. Sugiyama, et al.: Phys. Rev. ST Accel. Beams 12 (2009) 082801.

17) M. Mori, M. Kando, H. Kotaki, Y. Hayashi, S. V. Bulanov, J. K. 
Koga, K. Kondo, A. S. Pirozhkov, H. Nishimura, and K. Nagashima: J. Phys. Soc. Jpn. 80 (2011) 105001.

18) E. Esarey, R. F. Hubbard, W. P. Leemans, A. Ting, and P. Sprangle: Phys. Rev. Lett. 79 (1997) 2682.

19) C. B. Schroeder, P. B. Lee, and J. S. Wurtele: Phys. Rev. E 59 (1999) 6037.

20) E. Esarey, C. B. Schroeder, W. P. Leemans, and B. Hafizi: Phys. Plasmas 6 (1999) 2262.

21) H. Kotaki, S. Masuda, M. Kando, and J. K. Koga, and K. Nakajima: Phys. Plasmas 11 (2004) 3296.

22) G. Fubiani, E. Esarey, C. B. Schroeder, and W. P. Leemans: Phys. Rev. E 70 (2004) 016402.

23) J. Faure, C. Rechatin, A. Norlin, A. Lifschitz, Y. Glinec, and V.
Malka: Nature 444 (2006) 737.

24) H. Kotaki, I. Daito, M. Kando, Y. Hayashi, K. Kawase, T. Kameshima, Y. Fukuda, T. Homma, J. Ma, L.-M. Chen, et al.: Phys. Rev. Lett. 103 (2009) 194803.

25) C. Rechatin, X. Davoine, A. Lifschitz, A. Ben Ismail, J. Lim, E. Lefebvre, J. Faure, and V. Malka: Phys. Rev. Lett. 103 (2009) 194804.

26) T. Hosokai, M. Kando, H. Dewa, H. Kotaki, S. Kondo, N. Hasegawa, K. Nakajima, and K. Horioka: Opt. Lett. 25 (2000) 10.

27) A. J. Gonsalves, T. P. Rowlands-Rees, B. H. P. Broks, J. J. A. M. van der Mullen, and S. M. Hooker: Phys. Rev. Lett. 98 (2007) 025002 .

プラズマ波の破砕 (wave breaking of plasma waves)

プラズマ中の電子振動により生成されるプラズマ波 が，乱れ壊れること．プラズマ中に集光されたレーザー は，プラズマ中の電子を押しのけながら進む，その電子 は, プラズマ中のイオンに引かれ振動し，プラズマ波を 作る，船の後ろにできる波や，海岸に打ち寄せる波が， 振幅が小さいうちはきれいな正弦波であるのに，振幅が 大きくなったり, 障害物があったりすると, 正弦波を保 てなくなる. 同様に, レーザー強度が高くなりプラズマ
波の振幅が大きくなったり，急激な密度勾配等の障害物 があったりすると, 波が乱れ壊れる。これが, プラズマ 波の破砕である。この破砕により，ウェーク場への電子 入射が可能となる。しかし，ウェーク場はプラズマ波 (電子の疎密)によって生成されるため, プラズマ波の乱 れによりウェーク場も乱れ, 電子加速が不安定になる.

(小㴰 秀行) 